\title{
Fruiting Species Influence the Seasonal Use of the Habitat by Sloth Bear in and around Balaram Ambaji Wildlife Sanctuary, Gujarat, India
}

\author{
Tana P. MEWADA ${ }^{1 *}$, Umeshkumar L. TIWARI ${ }^{2 *}$, Amit KOTIA $^{3}$ \\ ${ }^{1} 15$ Dayalkripa Society, Nr GEB Sub Station, Gotri Road, Vadodara, 390021 Gujarat, India; tanashahi@gmail.com \\ ${ }^{2}$ Botanical Survey of India, Arunachal Pradesh Regional Centre, Itanagar, Arunachal Pradesh, \\ India; tigerumesh11@gmail.com (" correspondingauthor) \\ ${ }^{3}$ University of Rajasthan, Department of Botany, Jaipur, Rajasthan, India; kotia.amit@gmail.com
}

\begin{abstract}
Sloth bear populations in India are threatened, and the ecology and distribution of the species occurring in the region's protected areas are known, but there is no scientific basis underlying management strategies for sloth bear. We used bear indirect and opportunistic direct signs like feeding site, scats, foot print trails, claw marks on climbing trees, to study habitat use and distribution of sloth bear (Melurus ursinus) across Balaram Ambaji Wildlife Sanctuary and Danta Reserve Forest, Gujarat, India from April, 2010 to January 2011. We survey 40 grids $(5 \times 5 \mathrm{~km}) 3 \mathrm{~km}$ signs survey $=120 \mathrm{~km} \times 3=360 \mathrm{~km}$ and total 766 bear signs were recorded, and for vegetation we surveyed 40 grids $\times 2 \mathrm{~km}$ vegetation transect $=80 \mathrm{~km}$ were sampled. A total of nine (9) vegetation types were recorded and the bear sign where crossed check with the vegetation forest type. Fruits appear to be a key resource for sloth bears, and factors affecting fruit abundance or seasonality will affect bear foraging as well as the humans to depend on such fruits as a food common resource. Knowledge of this relationship will allow managers to be more proactive in managing bears. We recommend using sign surveys for monitoring changes in sloth bear presence, as they are inexpensive, efficient, and can be conducted by trained rangers.
\end{abstract}

Keywords: Balaram Ambaji Wildlife Sanctuary; Gujarat; India; sloth bears

\section{Introduction}

The sloth bear is an access wide variety of habitats, including wet or dry tropical forests, savannas, scrubland and grasslands (Joshi et al., 1995; Garshelis et al., 1999a; Akhatar et al., 2004; Ratnayeke et al., 2007; Mewada, 2015). In Gujarat out of five protected areas where sloth bear occurs, i.e. Shoolpaneshwar, Jambughoda, Ratanmahel, Jassore and Balaram-Ambaji Wildlife Sanctuaries (Mewada and Dharaiya, 2010; Mewada 2015). According to Garshelis et al. (1999b) Balaram Ambaji and Jassore Wildlife Sanctuaries were having highest sloth bear densities than anywhere in India. North Gujarat forests, which is very sparse, patchy and dryer forested areas have created sloth bear image frightening among the locals of Balaram-Ambaji Wildlife Sanctuary (BAWLS), Danta Reserved Forest (DRF) of Banaskantha district. In BAWLS and DRF, habitats available to sloth bears are highly disturbed, smallclustered forested patches with small human settlements in between and agriculture fields (Mewada and Dharaiya, 2010). Moreover, people increasingly collect non-timber forest produce (NTFP), which leads to confrontation with bears. It has great concern for the conservation and management issues with local people and sloth bear, whose status is vulnerable and precarious. The human-bear conflicts are on a hike, which needs checking and attention to resolve, for conservation of threatened species and management in defragmented and small forest patches (Murthy and Shankar 1995; Chauhan et al., 1999; Dharaiya and Ratnayeke, 2009; Mewada and Dharaiya, 2010).

As off now scattered information is available on the habitat use, food, habitat, activity and movement patterns and behaviour of sloth bears in these forested areas of BAWLS and DRF, and nothing is known to man-altered situations in North Gujarat forests. Habitats available for sloth bears within the ranges are namely, Danta East, Danta West, Ambaji North, Ambaji South, Amirghad and Palanpur ranges and along highly degraded surrounding forests. Optimum habitats that can support the population of sloth bears in these areas are very less but inside and fringed of these forested areas, some of the boulders with small hillocks are available, these habitats offer suitable 'den' sites for sloth bears which are quite close to human settlements. Due to which sloth bears are forced to use these degraded forested areas, both bears and humans dwell 
184

smoothly in these forested areas for the common resource dependency. With this study authors just tried to analyse the bear diet and the distribution of fruiting trees. By knowing, the seasonal food preference and the forest patches, which are having a high density of the fruiting trees, can be utilized for the management purpose to reduce the conflict and helps in effective conservation of the sloth bear.

\section{Materials and Methods}

\section{Study area}

The Banaskantha district lies between $23^{\circ} 35^{\prime}$ to $24^{\circ} 43^{\prime}$ North latitudes and $71^{\circ} 0^{\prime}$ to $73^{\circ} 0^{\prime}$ East longitudes on the Banas River. The district is in the Northwestern a part of the Gujarat and shares its boundary with Rajasthan state. The total area of Banaskantha district is $10754.7 \mathrm{~km}^{2}$, which constitutes $5.5 \%$ percent of the total area of the State. From the viewpoint of area, the district is the third largest in the state. Banaskantha district is spread over flat desert like saline area in the west and undulating and hilly terrain in the north and the northwest area. The total forest area covered under the Banaskantha district reported is 1605.64 $\mathrm{km}^{2}$ out of which $970.84 \mathrm{~km}^{2}$ is Reserved Forest; $18.74 \mathrm{~km}^{2}$ is protected forests and $616.06 \mathrm{~km}^{2}$ is unclassified forest.

The abiotic environment of the North Gujarat Region (NGR) experiences a high variation in temperature with minimum going down to $5{ }^{\circ} \mathrm{C}$ in winter and maximum to $46^{\circ} \mathrm{C}$ in summer. Usually the monsoon season experiences an average rainfall of $765 \mathrm{~mm}$, which provides ideal environmental condition for the occurrence and abundance of diverse flora and fauna. The topography varies from plains with an elevation gradients of $10 \mathrm{~m}$ to $600 \mathrm{~m}$ above MSL. The forest tracts of the area are highly undulating with broken ranged of hill in height ranging from 170 to 600 (MSL) meter above sea level. Most of the hilly tract is highly sloppy with almost 90 to 100 percent slopes in places. The important hills of the study area are Koteshwar, Gabbar, Surmata hills, Diwania hills, Kaleto hills, Trishulia hills, Virampur hills, Hathidra hills and Chamunda hills. These hills and hillocks are forming a network leading to the bigger mullahs, entering the plains and draining into the river Banas (Singh et al., 2002).

The biotic units of the area by its flora in the forest is classified by Champion and Seth (1968), this region supports Southern dry mixed deciduous forests 4B3, 4B4 (5A/C3) which is further classified into its subgroups $5 / \mathrm{E} 1$, 5/E1/DS1, 5/E2, 5/E5, 5/E7 and 5/E9. The forest on hills supports a very good population of Boswellia and Lannea forests at the top, at the middle of the hills covered by the Acacia and at the foothills are dominated by Anogeissus forests. Apart from these species, the Ambaji range supports good density of the teak (Tectona grandis), and bamboo species. The unique ecosystem harbours 483 species of plants including 107 of trees, 58 of shrubs, 219 of herbs, 49 of climbers, 40 of grass and 10 species of lower plants (Pandey, 2004). Among the fauna, the area supports good diversity of the ground dwelling birds and the other migratory wetland birds in migratory season. Mammalian fauna is recorded very less in the region. Bluebull (Boselaphus tragocamalus) is one of the most common large mammals in entire area, while other ungulate population is found too low in the region. There are more records of small to medium sized carnivores/omnivores like small Indian civet (Viverricula indica), jungle cat (Felis chaus), Indian ratel (Mellivora capensis), sloth bear (Melursus ursinus) and leopard (Panthera pardus). According to the study carried out by Dharaiya (2008-2009) recorded 28 species of mammals for the entire North Gujarat region.

\section{Methodology}

The first few days were devoted for general reconnaissance of the areas to get an idea of the forest cover types. Different habitat used by sloth bear were categorised and random sampling were done to quantify the vegetation. Primary analysis has been carried out to obtain the values of various parameters for calculating grid base sampling. A grid of $5 \times 5 \mathrm{~km}$ lay on BAWLS map and in each grid vegetation transect were laid of $1 \mathrm{~km}$ length. Each grid was identified having forested area and selected for sign survey trails (SST). Sloth Bear sign information was collected from grid survey, $3 \mathrm{~km}$ in each selected grid were walked, bear sign was recorded, and an encounter rate was calculated. Detect ability of mammal sign may vary among different habitats and among types of sign. To minimize biases due to varying detectability rates, we used a fixed-width SST and only considered Sloth Bear sign within $5 \mathrm{~m}$ on either side of the SST (10 m transect width) (Fig. 1A).

For the bear survey: The study areas were regularly surveyed by inspecting bear signs in $5 \times 5 \mathrm{~km}$ grid overlaid on 1:50,000 scale map to determine presence or absence of sloth bear. The sign survey was also supported by interviews of local villagers for first-hand knowledge of the visiting forests in the area who would be more likely to report on the presence or absence of sloth bears. With assistance from local tribesmen, we verified reports from villages by surveying grid cells for sloth bear sign such as tracks, scats and diggings; to identify areas used by sloth bears. All locations of the tracks, scats or another were mapped using a Garmin GPS.

A supervisory classification was done using fieldcollected data on habitat characteristics. The habitat types were identified primarily on structure of vegetation communities.

For the vegetation survey: The first few days were devoted for general reconnaissance of the areas to get an idea of the forest cover types. Different habitat used by sloth bear were categorised and random sampling are done to quantify the vegetation. Sampling of trees was done within $10 \mathrm{~m}$ radius circular plots which are repeated every $100 \mathrm{~m}$ point along the trail of $1 \mathrm{~km}$. Within $10 \mathrm{~m}$, radius plot tree and liana counted and inside $10 \mathrm{~m}$ radius plots, $5 \mathrm{~m}$ radius plots lay to count shrubs and climbers and two one (1) $\mathrm{m}^{2}$ plots on the N-S corner were laid for ground vegetation. Woody species exceeding $30 \mathrm{~cm}$ at $\mathrm{GBH}$ were considered as a tree, whereas less than $30 \mathrm{~cm}$ at $\mathrm{GBH}$ were considered as a shrub (Fig. 1B). 

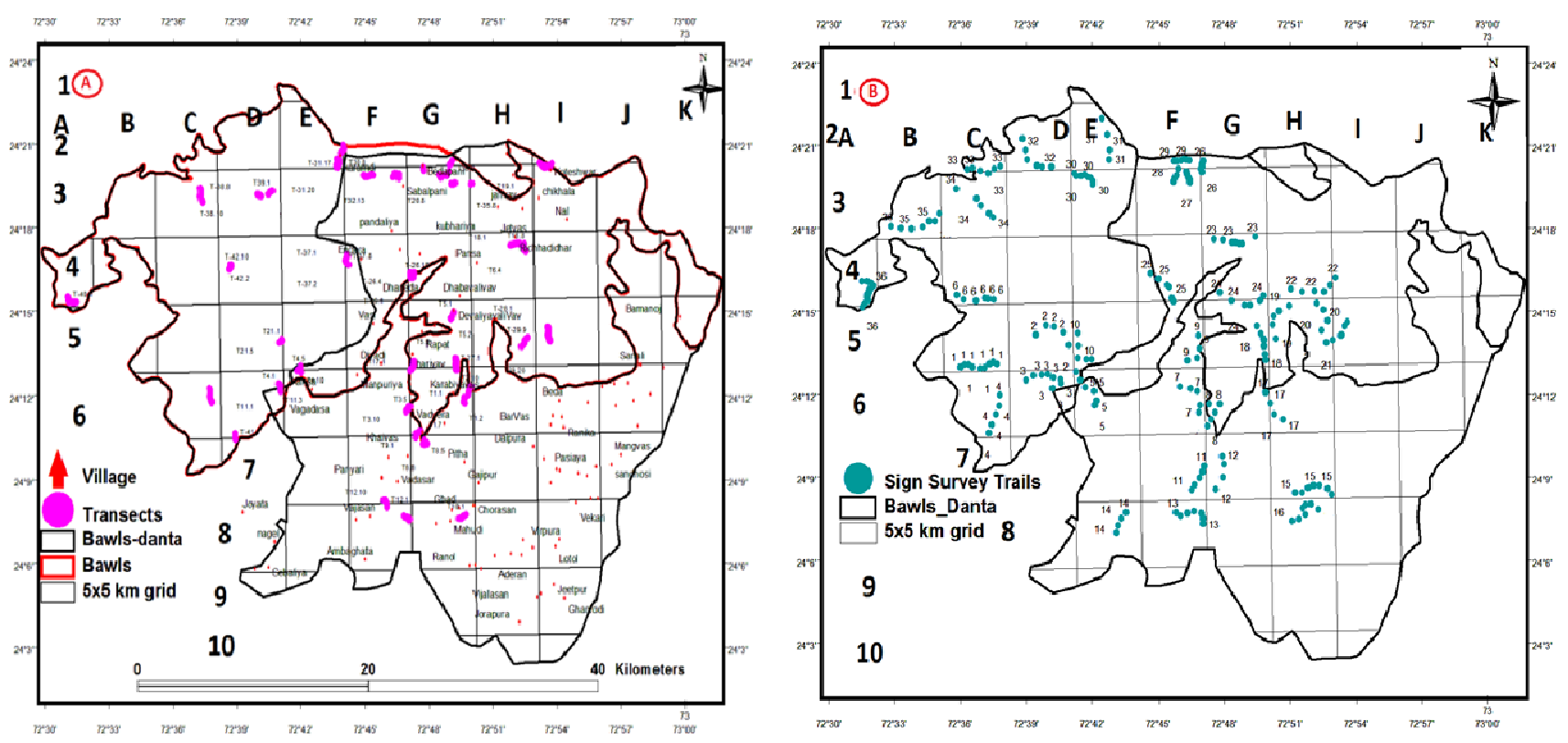

Fig. 1. A-Vegetation transects location in grid of study area; B- Sign survey trails in grid of study area

\section{Results}

Seasonal availability of the sloth bear food plant in different forest types of the study areas may help in knowing the seasonal forest use by the sloth bear. This study was carried out to identify available patches of high fruiting plants and frequently utilized by the sloth bear during its fruiting seasons.

Total $225 \mathrm{~km}$ sign survey was done in the study area $(25$ grids of $5 \times 5 \mathrm{~km}, 3 \mathrm{~km}$ SST were walk for three different seasons; 25 grids $\times 3 \mathrm{~km}=75 \mathrm{~km} \times 3=225 \mathrm{~km}$ ) and total 766 bear signs were recorded in which scats (67\%), foot print $(14 \%)$, scratches on the land and on the tree trunks, etc. $(8 \%)$, trail (series of footprints in a walk) $(5 \%)$ as the area are much rockier or the gravel base so the continuous footprint or the trail reports was difficult in this area. During the entire period of survey only $3 \%$ of digging was observed, it is because the soil is very hard to dig out. Only $2 \%$ feeding site were located during the study period, which are mainly fruits, honeycomb and water holes. Only one time direct sighting of SB was observed during sign survey (Fig. 2).

In the study area, nine different vegetation types were observed and apart from these two unique habitat types were also observed i.e., boulders and rocky. The boulder area mainly harbours large stones or boulders, which can be considered as very good den, site for the sloth bear for relaxing and conceal during the inactive period (daytime) in the area. It is clearly seen in the Fig. 3 that the boulder habitat is much-used ( $2.89 \mathrm{sign} / \mathrm{km}$ walk) by the bear than the rocky habitat $(0.44 \mathrm{sign} / \mathrm{km}$ walk). Maximally used habitat was reported in the Riverine forest $(4.11 \mathrm{sign} / \mathrm{km}$ walk) which is followed by boulder (2.28 sign $/ \mathrm{km}$ walk), crop fields (2.56 sign $/ \mathrm{km}$ walk), PABMF= Prosopis, Acacia mixed forest (2.04 sign $/ \mathrm{km}$ walk), $\mathrm{ZMF}=$ Ziziphus mixed forest (1.74 sing $/ \mathrm{km}$ walk), P scrubs= Prosopis scrubs $(1.41$ sign $/ \mathrm{km}$ walk), MF=Mixed Forest (1.33 sign $/ \mathrm{km}$ walk), D scrubs $=$ Diospyros scrubs (1.22 sign $/ \mathrm{km}$ walk $)$ and DMC scrubs = Diospyros- Miliusa and Cassia scrubs (1.06 sign $/ \mathrm{km}$ walk) (Fig. 3).

Fig. 4. A and B and Table 1 represents the grid wise sign encounter rate and locations of transects along with conflict zone. Very high sign encounter rate (VHER) was recorded in grid F8 and nearby villages of Vajsan and Ambaghat; high sign encounter rate (HER) of sloth bear was recorded in grid number A4, F3 and H5 and nearby villages of Sabal Pani, Piplivav and Dhablivav. While it is clear that, the sloth bear habitat use in the study area is more or less uniformly.

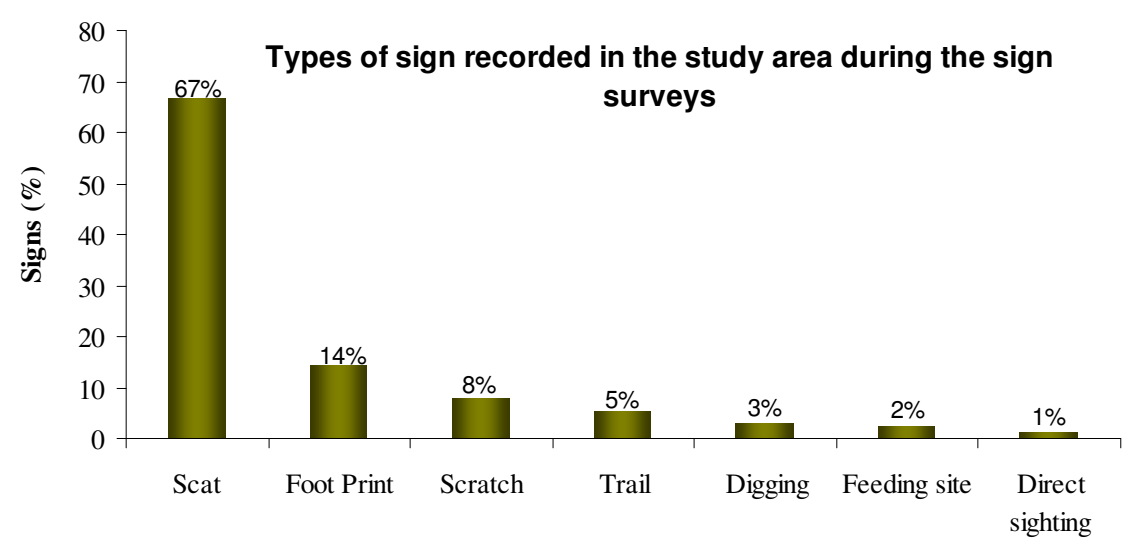

Fig. 2. Types of sloth bear sign recorded in the study area during the sign survey 
186

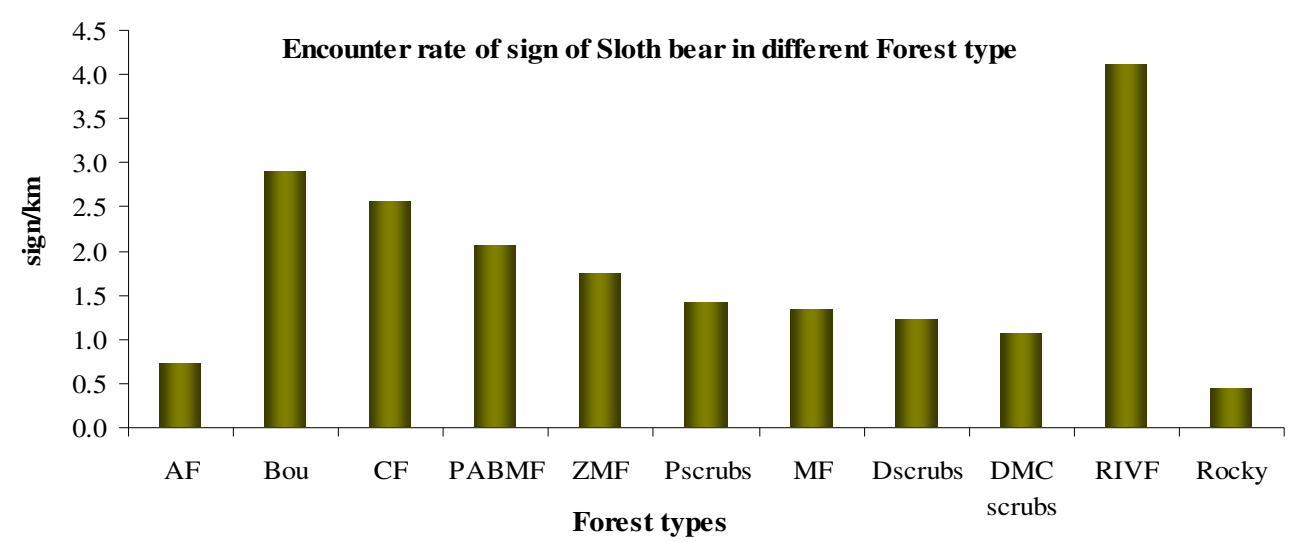

Fig. 3. Encounter rate of the sloth bear sign evidences in different forest types of the study area, AF= Acacia Mix Forest, Bou. = Boulders, CF $=$ Crop Filed, DMC scrubs= Diospyros, Miliusa, Cassia scrubs, D scrubs= Diospyros scrubs, MF=Mix Forest, $\mathrm{PABMF}=$ Prosopis, Acacia, Butea, Mix Forest, $\mathrm{P}$ scrubs $=$ Prosopis scrubs, RIVF $=$ Riverine Forest, $\mathrm{ZMF}=$ Ziziphus Mix Forest
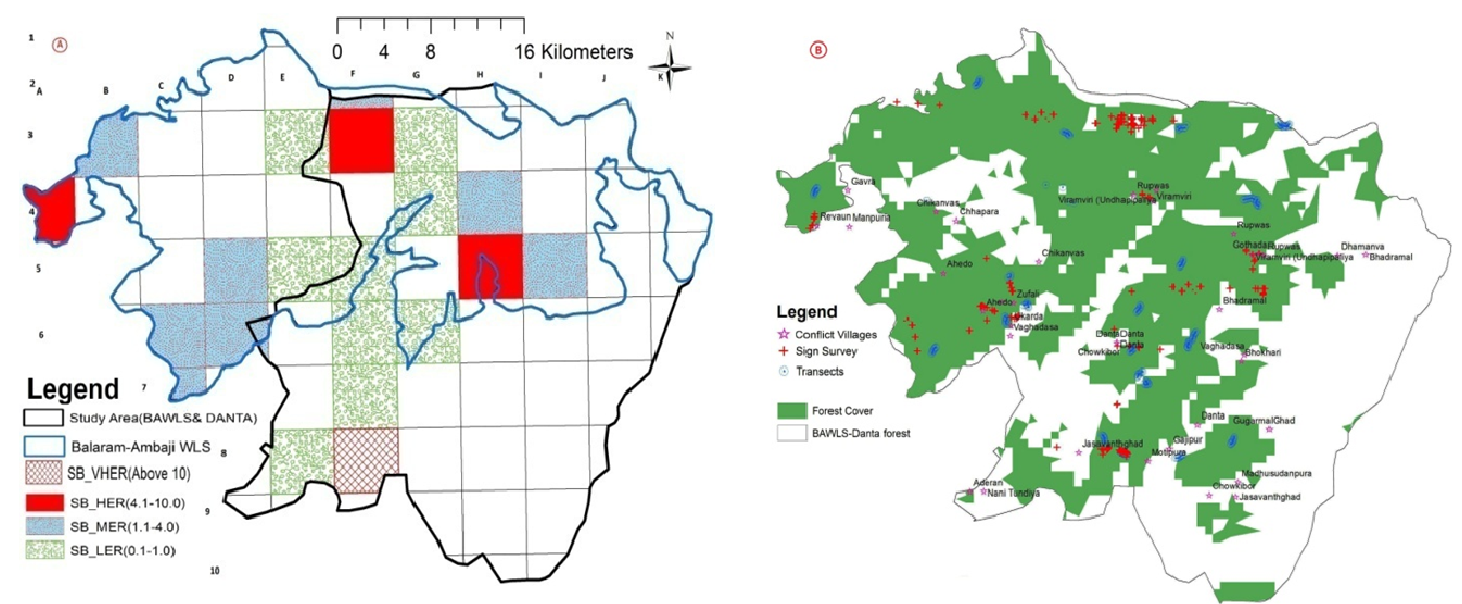

Fig. 4. A- Distribution of the sloth bear sign encounter rate in different grids of the study area; B- Sign survey trails in different forests of the study area

Table 1. Encounter rate of sloth bear sign in the study area shown grid wise $($ sign $/ \mathrm{km}$ in the $5 \times 5$ grid $)$

\begin{tabular}{|c|c|c|c|c|c|c|c|c|c|c|c|}
\hline Grids & A & B & $\mathrm{C}$ & $\mathrm{D}$ & $E$ & $\mathrm{~F}$ & $G$ & $\mathrm{H}$ & I & $\mathrm{J}$ & $\mathrm{K}$ \\
\hline 1 & -. & -. & -. & -. & -. & -. & -. & -. & -. & -. & - \\
\hline 2 & - & - & 0.67 & - & -. & 2.44 & - & - & -. & -. & -. \\
\hline 3 & - & 1.33 & - & - & 0.44 & 7.11 & 0.67 & - & - & - & - \\
\hline 4 & 5.00 & - & -. & - & - & - - & 0.67 & 1.33 & - & - & - \\
\hline 5 & - & - & - & 2.44 & 1.00 & 0.33 & -- & 7.33 & 2.67 & - & - - \\
\hline 6 & - & - & 4.00 & 3.67 & 0.67 & 0.67 & 0.67 & - & - & - & - \\
\hline 7 & - & - & 1.33 & - & - & 0.33 & -. & - & - & - & - \\
\hline 8 & - & -. & -. & - & 0.33 & 10.67 & 5.00 & -- & -. & -. & -. \\
\hline
\end{tabular}

Overall, 190 plots (10 m radius) were laid covering 9 different forest types. In mixed forest types, maximum numbers of trees were observed (Table 2) and maximum density was observed for Diospyros melanoxylon followed by Miliusa tomentosa. Maximum density of Ziziphus mauritiana was observed in Acacia tortilis scrub forest. Good population of Cassia fistula was found in Diospyros and Butea mixed forest. The Cassia fistula is distributed mainly in the central part of the sanctuary this species locally known as Garmalo (Amaltash), this is also an important medicinal plant. The plant occurs in the grid E-5, E-6 and I3 in high densities and lowest densities in grid E-2, D-6, F-8 and G-5. This species is present in Sloth Bear scats throughout the year and available $26.32 \%$ in monsoon, $7.36 \%$ in winter and $34.29 \%$ during summer, and supports Sloth Bear food for the whole year. The highest density of C. fistula is 35.03 per ha and the lowest density is 3.18 per ha. Diospyros melanoxylon is distributed in the central part of the sanctuary this species locally known as timru (Tendu), this is an important NTPF collection plant for India. The plant occurs in the grid G-6, G-7, H-5 and I-4 with the highest density and with low density in grid D-5, D-6, F-7, F-8 and I-3. This species is present in sloth bear scats during monsoon $30.70 \%$ and $13.71 \%$ during the 
summer. Ficus benghalensis, Ficus virens and Ficus racemosa are three species distributed in the sanctuary. Ficus group is an important fruit plant for all frugivorous species of any forest and are mainly distributed in the central to northern part of the sanctuary, locally known as Vad, Pepar and Gular respectively. The plant occurs in high density in the grid G5 and lowest densities in grid F-1, H-3 and I-3. This species is present in sloth bear diet and found whole year. These species has detected $26.32 \%$ during monsoon, $10.29 \%$ summer and $5.52 \%$ during winter. The highest density of Ficus benghalensis is 25.48 per ha. Whereas, the minimum density is 3.18 per ha for both the Ficus species. Madhuca indica is distributed in the east-northern part of the sanctuary and locally known as Mahudo (Mahua), this is known as one of liquor plants in India. The plant occurs in the grid I-2 with highest densities and $\mathrm{H}-2$ with lowest densities. This species is reported during the summer when flower blooms 2.29\%, as the maximum flower was taken as food, which shows the low frequency because of flower digest, and remaining, which can be detected form scats are very less. The highest density of Madhuca indica is 28.66 per ha and minimum density is 6.37 per ha in the study area. Another important species for sloth bear diet, Phoenix sylvestris is distributed at the central part of the sanctuary this species locally known as Khajuri. The fruit of Phoenix species is well known for their nutrient value. The plant occurs in the grid G-4 and G-5. This species is present in summer diet $28.00 \%$ and $9.65 \%$ in monsoon. The Syzygium cumini and Syzygium heyneanum are two species distributed in the sanctuary, $S$. cumini is distributed in the northern part of the sanctuary this species occur in high density in grid $\mathrm{H}-4$ with 47.77 per ha whereas, the lowest density is 3.18 per ha distributed in I-2 and H-3 grids. Beside this $S$. heyneanum is distributed in southern part in the single grid F-7 with the 12.74 density per ha. Syzygium species is present $33.33 \%$ in the scats of sloth bear in monsoon; fruit of S. cumini is preferred fruit of sloth bear. Ziziphus mauritiana is dominant among all the Ziziphus species, it occurs high density in G-5 with 101.82 per ha and G-2, F-5 and G-6 with low density around 25.48 to 9.55 per ha. Ziziphus species are important winter diet of the bear and reported $23.93 \%$ and if late fruiting is remaining is some of the plants in the study area was reported in the summer diet $3.43 \%$ and late fruiting found in the some plants during end of monsoon seasons supports $3.43 \%$.

As this study area comes under the dry, semi-arid zone, in spite of that, in good numbers fruiting species are available in the forest. Maximum varieties of fruiting species for the sloth bear were observed in mix forest types, they are available throughout the year for sloth bear followed by Acacia tortilis scrub forest, and least fruiting species for sloth bear are recorded in Wrightia and Miliusa mixed forest and Acacia catechu and Acacia tortilis forest (Table 3). Maximum food plants are available in mixed forest and throughout the year (Table 3). While very less food plants were available in the Wrightia and Butea forest, Wrightia and Miliusa mixed forest types and clearly seen that, it hardly supports the bear food for the 3 months in a year namely June, July and August. Table 4 shows the fruiting plant species and there seasons in different forest types of study areas.

Table 2. List of tree species with their density and frequency in different forest types of study area (1-Acacia tortilis scrub forest, 2-Diospyros and Butea mixed forest, 3-Acacia catechu and Acacia tortilis forest, 4-mixed forest, 5-riverine forest, 6-teak and Miliusa mixed forest)

\begin{tabular}{|c|c|c|c|c|c|c|c|c|c|c|c|c|}
\hline \multirow{3}{*}{ Plant species name } & \multicolumn{2}{|c|}{$1(n=30)$} & \multicolumn{2}{|c|}{$2(n=10)$} & \multicolumn{2}{|c|}{$3(\mathrm{n}=10)$} & \multicolumn{2}{|c|}{$4(\mathrm{n}=110)$} & \multicolumn{2}{|c|}{$5(\mathrm{n}=10)$} & \multicolumn{2}{|c|}{$6(n=10)$} \\
\hline & $\mathrm{D}$ & $\mathrm{F}$ & $\mathrm{D}$ & $\mathrm{F}$ & $\mathrm{D}$ & F & $\mathrm{D}$ & F & $\mathrm{D}$ & $\mathrm{F}$ & $\mathrm{D}$ & $\mathrm{F}$ \\
\hline & $\mathrm{ha}^{-1}$ & (\%) & $\mathrm{ha}^{-1}$ & (\%) & $h a^{-1}$ & (\%) & $\mathrm{ha}^{-1}$ & (\%) & $h^{-1}$ & (\%) & $\mathrm{ha}^{-1}$ & (\%) \\
\hline Aegle marmelos & 4.78 & 15.00 & 6.37 & 10.00 & 35.03 & 10.00 & -- & -. & -- & -- & 12.74 & 30.00 \\
\hline Alangium salvifolium & 17.52 & 25.00 & -. & - & -. & -. & 10.42 & 10.91 & -. & -. & 25.47 & 20.00 \\
\hline Anonna squamossa & -. & -. & - & - - & -. & -. & - - & - - & -- & - - & - & -. \\
\hline Cassia fistula & 1.59 & 5.00 & 95.39 & 100.00 & - & -. & 6.37 & 10.91 & - & -- & -- & - \\
\hline Cordia dicotoma & -- & -- & 3.18 & 10.00 & -. & - & 0.29 & 0.91 & -- & -- & -. & -. \\
\hline Diospyros melanoxylon & 4.78 & 10.00 & - & -. & -. & - & 33.58 & 51.82 & 25.44 & 50.00 & 47.69 & 70.00 \\
\hline Emblica officinalis & -- & -. & -. & -. & -. & -. & -- & - & -. & -- & 3.18 & 10.00 \\
\hline Feronia limonia & 6.37 & 10.00 & 6.35 & 10.00 & - & - & 2.32 & 4.55 & - & -- & -- & - \\
\hline Ficus benghalensis & - & - & -- & -. & -- & - & 2.90 & 4.55 & $-\cdot$ & -- & -. & -. \\
\hline Madhuca indica & - & - & 9.52 & 20.00 & - - & - & 5.21 & 10.00 & 28.58 & 30.00 & 15.88 & 40.00 \\
\hline Manilkara bexandra & -. & -. & 6.35 & 10.00 & -- & -. & -- & -- & -- & -- & -- & -- \\
\hline Miliusa tomentosa & -. & - & - & - & -- & - & 19.69 & 25.45 & 12.69 & 30.00 & 133.29 & 90.00 \\
\hline Phoenix sylvestris & -. & -. & - & -. & -- & -. & 0.58 & 0.91 & -- & -- & -- & -- \\
\hline Pongamia pinnata & 17.52 & 15.00 & - & - & - & - & 5.79 & 7.27 & 12.69 & 20.00 & -. & -. \\
\hline Syzygium cuminii & $-\cdot$ & $-\cdot$ & 6.34 & 10.00 & -- & - & 0.87 & 0.91 & 3.17 & 10.00 & -. & -- \\
\hline Syzygium heyneanum & 6.37 & 5.00 & - & - & - & - & - & - & -- & -. & -- & -- \\
\hline Terminalia belerica & - & -- & - & -- & -- & -- & 1.45 & 2.73 & 6.34 & 20.00 & 25.35 & 40.00 \\
\hline Ziziphus mauritiana & 78.03 & 65.00 & - & - & - & - & 4.34 & 6.36 & -- & $-\cdot$ & -. & -. \\
\hline Ziziphus xylopyrus & -. & -. & -. & -. & 9.50 & 10.00 & 1.74 & 2.73 & -. & -. & -. & -- \\
\hline
\end{tabular}


Table 3. Sloth bear food plant's availability in the forests of Danta and BAWLS (Months from March to February)

\begin{tabular}{|c|c|c|c|c|c|c|c|c|c|c|c|c|c|}
\hline \multirow[b]{2}{*}{ Fruiting time in different forest types } & \multirow{2}{*}{$\begin{array}{l}\text { No. of } \\
\text { fruiting } \\
\text { species }\end{array}$} & \multicolumn{12}{|c|}{ Months } \\
\hline & & M & A & M & $\mathrm{J}$ & $\mathrm{J}$ & A & S & $\mathrm{O}$ & $\mathrm{N}$ & $\mathrm{D}$ & $\mathrm{J}$ & $\mathrm{F}$ \\
\hline Acacia tortilis Scrub Forest & 8 & 2 & 3 & 5 & 5 & 4 & 2 & 1 & 2 & 2 & 2 & 2 & 2 \\
\hline Diospyros and Butea Mixed Forest & 6 & 0 & 1 & 2 & 3 & 3 & 3 & 0 & 0 & 2 & 2 & 1 & 0 \\
\hline Acacia catechu and Acacia tortilis Forest & 2 & 1 & 1 & 1 & 1 & 1 & 0 & 0 & 1 & 1 & 1 & 1 & 1 \\
\hline Mixed Forest & 13 & 2 & 4 & 8 & 8 & 6 & 5 & 3 & 4 & 4 & 4 & 4 & 3 \\
\hline Riverine Forest & 4 & 0 & 1 & 3 & 3 & 2 & 2 & 0 & 0 & 0 & 0 & 0 & 0 \\
\hline Teak and Miliusa Mixed Forest & 6 & 1 & 2 & 4 & 4 & 2 & 2 & 0 & 0 & 1 & 1 & 1 & 0 \\
\hline Wrightia and Butea Forest & 3 & 0 & 0 & 1 & 2 & 2 & 2 & 0 & 0 & 0 & 0 & 0 & 0 \\
\hline Wrightia and Diospyros Mixed Forest & 4 & 0 & 0 & 2 & 4 & 3 & 3 & 1 & 1 & 0 & 0 & 0 & 0 \\
\hline Wrightia and Miliusa Mixed forest & 2 & 0 & 0 & 1 & 2 & 2 & 2 & 0 & 0 & 0 & 0 & 0 & 0 \\
\hline
\end{tabular}

Table 4. List of food plants available in different forest types of study area (1-Acacia tortilis scrub forest, 2-Diospyros and Butea mixed forest, 3-Acacia catechu and Acacia tortilis forest, 4-Mixed Forest, 5-Riverine forest, 6-teak and Miliusa mixed forest, 7-Wrightia and Butea forest, 8-Wrightia and Diospyros mixed forest, 9-Wrightia and Miliusa mixed forest)

\begin{tabular}{|c|c|c|c|c|c|c|c|c|c|c|c|c|c|}
\hline Species Name & Forest types & Mar & Apr & May & Jun & Jul & Aug & Sep & Oct & Nov & Dec & Jan & Feb \\
\hline Aegle marmelos & $1,3,6$ & + & + & + & + & + & & & & & & & \\
\hline Alangium salvifolium & $1,4,6,8$ & & & + & + & & & & & & & & \\
\hline Annona squamosa & 2 & & & & & & & & & + & + & & \\
\hline Cassia fistula & $1,4,7$ & + & + & + & + & + & + & + & + & + & + & + & + \\
\hline Cordia dicotoma & 4 & & & + & + & & & & & & & & \\
\hline Diospyros melanoxylon & $1,2,4,5,6,7,8,9$ & & & + & + & + & + & & & & & & \\
\hline Emblica officinalis & 2,6 & & & & & & & & & + & + & + & \\
\hline Feronia limonia & 1,4 & & + & + & + & & & & & & & & \\
\hline Ficus benghalensis & 4 & + & + & + & + & + & + & + & + & + & + & + & + \\
\hline Madhuca indica & $2,4,5,6$ & & + & + & & & & & & & & & \\
\hline Miliusa tomentosa & $2,4,5,6,7,8,9$ & & & & + & + & + & & & & & & \\
\hline Phoenix sylvestris & $2,4,8$ & & & & + & + & + & + & + & & & & \\
\hline Syzygium cumini & $1,4,5$ & & & + & + & + & & & & & & & \\
\hline Syzygium heyneanum & 1 & & & & + & + & & & & & & & \\
\hline Ziziphus mauritiana & $1,3,4$ & & & & & & & & + & + & + & + & \\
\hline Ziziphus xylopyrus & 4 & & & & & & & & & + & + & + & + \\
\hline
\end{tabular}

26 species of fruiting plants available in the study area and these fruits are preferred by the sloth bear in BAWLS and Danta RF. Season wise representation of fruiting plants is provided in Table 5.

\section{Discussion}

Sign and sightings may be used to define bear distribution (essentially a presence-absence), and changes in distribution may signify changes in abundance (Laurie and Sedensticker, 1977; Rossell and Litvaitis, 1991). Despite myrmecophagous habits, sloth bears are omnivorous and consume large amounts of vegetable matter, particularly fruits (Laurie and Seidensticker, 1977; Gopal, 1991; Gokula, 1991, Litvaitis and Kane, 1994; Gokula et al., 1995). Studies of movement patterns of sloth bears showed that home-range size mainly depended on food supply (Joshi et al., 1995, Desai et al., 1997).

Akhatar et al. (2004) found total 30 different food items were in scats $(\mathrm{n}=1086)$. Which shows the fruits of gular (Ficus racemosa), pakri (F. virens), bargad (F. benghalensis), peepal $(F$. religiosa), ber (Ziziphus mauritiana), bel (Aegle marmelos), jamun (Syzygium cumini) and mahua (Madhuca indica) in addition to termites (Odontotermes obesus) and ants were major food items for sloth bears in MP. While in the present study, we analysed total 566 scats contains 36 food variants including 26 species of plants, 3 groups of insects, different unknown animal matters (bone, feather, etc.). Overall annual frequency occurrence of 26 plant and animal food items, khajur (P. sylvestris) and jamun $(S$. cumini) was occurred highest in plant matter in the scats of the sloth bear. Other fruits were also found seasonally like timru (Diospyros melanoxylon), bor (Ziziphus spp.), garmalo (Cassia fistula), gunndaa (Cordia dichotoma), Mahua (Madhuca indica) and mango (Mangifera indica).

According to Johnsingh (1981), the diet of sloth bear in Bandipur National Park, South India, is constituted of insects (53\%), fruits (37\%) and others (10\%) items. In Mundanthurai Wildlife Sanctuary, Gokula et al. (1995) has found the composition of bear diet constituted of insects (75\%), fruits (25\%) and other (1\%). An examination of 567 fresh scats at Mudumalai wildlife sanctuary, India, Bhaskaran et al. (1997) have found fruits as a major constituent in Sloth bear food. In another study at Mudumalai Wildlife Sanctuary, analysis of 478 scats revealed that the animal matter dominated (52\%) over the 
Table 5. Fruits availability in different seasons in a year for sloth bear

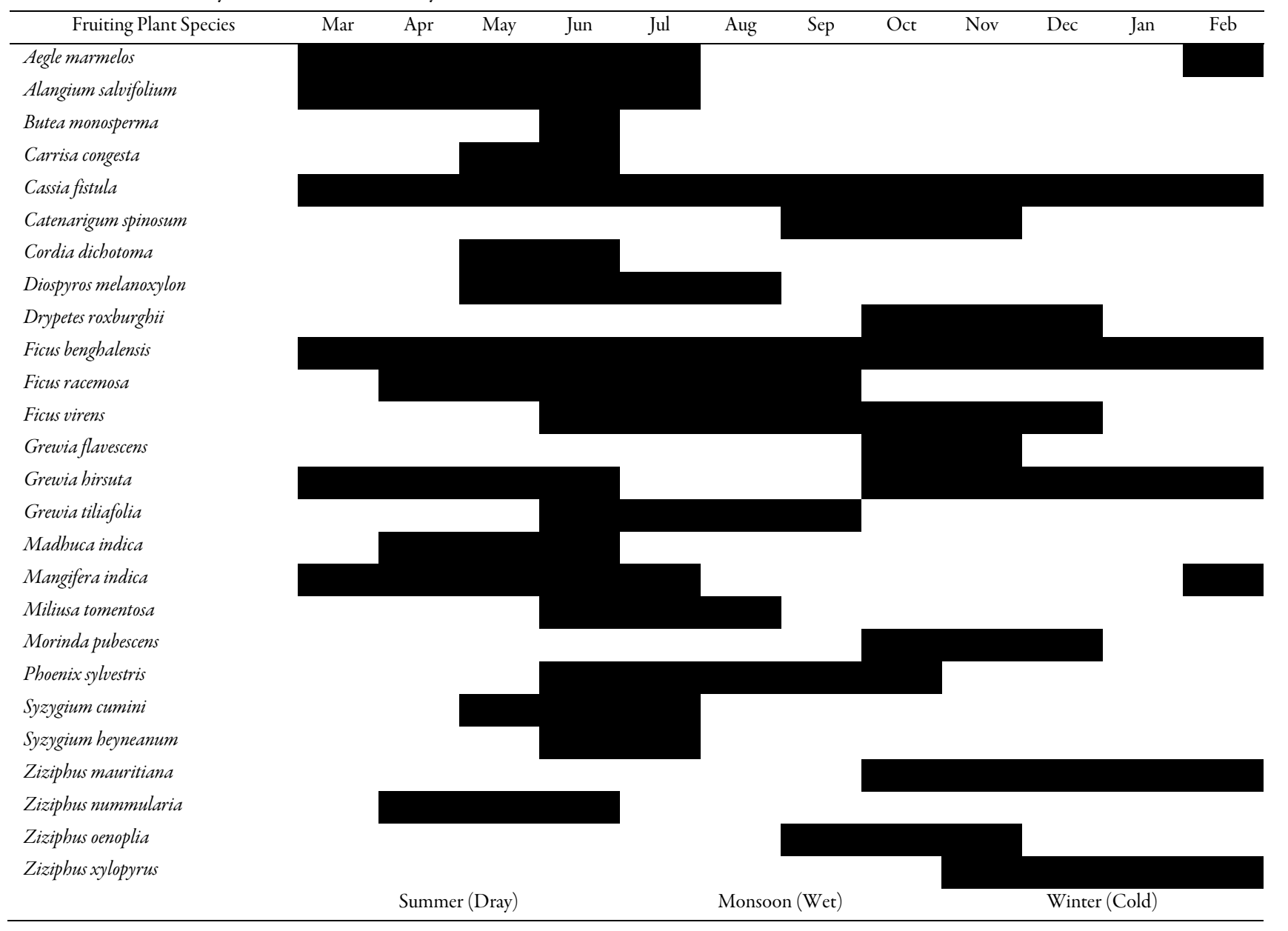

plant matter (48\%) (Desai et al., 1997). In Central India, (Kanha National Park), the diet composition of sloth bear composed of insects (39\%) and fruits (61\%), (Schaller, 1967). Whereas study by Yoganand et al. (2005) at Panna National Park fruits contributed 56\%, ants 29\% and termites $10 \%$ in the diet of sloth bear. Among fruits, Diospyros melanoxylon was the highest contributor, followed by $Z$. Mauritiana, and among insects, Cmponotus spp. of ants made the greatest contribution to the diet, followed by Dorylus labiatus ant. Termites contributed a smaller, but a consistent portion (about 10\% to 25\%) during most months. Fruits and ants complemented each other and constituted $70 \%$ to $95 \%$ of the diet (Yoganand et al., 2005). Mewada and Dharaiya (2010) reported the dietary composition of sloth bear from Vijayanage forested area of Sabarkantha district of Gujarat. They had observed that in summer, Ficus spp. (35\%), which is very common in that area and during monsoon and summer season diets (60 and $34 \%$ respectively). In winter, Cassia fistula was the fruit most frequently taken (84\%), along with insects (35\%). In a study in the Royal Chitwan National Park, it has been observed that bear fed on 17 different fruits (47\%) excluding flower, grass, honey and 6 different insects (52\%) (Laurie and Seidensticker, 1977). In a detailed study at Royal Chitwan National Park, Nepal, an analysis of 627 scats showed that diet composition of bears constituted insects (83\%), fruits (14\%) and others (3\%) (Joshi et al., 1997). All these research shows the importance of the fruit in the diet of sloth bear throughout the India. Based on such food habits the preferred fruiting trees in the forest definitely influence the habitat use in the seasonal selection bases. Ficus sps and Cassia fistula are two important species present in this forest type which are available throughout the year for sloth bear. Maximum movement of sloth bear was observed in Acacia tortilis scrub and mixed forest types in the study area. This supports the best food available and 15 species are available for sloth bear. Apart from this Wrightia and Millusa mixed and Diospyros and Butea mixed forest types are also good habitats and have good number of fruiting plants for sloth bear.

\section{Management implication}

This area is supporting good diversity and inhabited by the tribal communities, which are extensively depending on the forest product use in their day-to-day life. All most all tribal families of this area is involved in the collection of the NTFP (Non Timber Forest Product) or/and Miner Forest Product (MFP). The food is one of the common resources between Sloth bear, other wild animals, human and their livestocks, who, foraged on the same resources. This includes Ziziphus Spp., Diosyros melanoxylon, Phoenix sylvestris, Syzygium Spp., Madhuca indica and Ficus Spp.

The mixed forest supports more diverse fruiting tree, which make food (fruits) available to Sloth bear throughout the year. Here we would like to suggest the forest plantation and management authorities to study the area and plant 
190 accordingly a mixed fruiting species inside the forest. This may accomplish the bear requirement and advised the tribal to access these fruiting patches during the daytime. Leave the crepuscular and night hours to bear and diurnal hours for us. This may help in reducing the encounter with the bear. Adequate amount of food availability to bear may decrease the sloth bears come out of the forested area.

Educate tribal and forest dweller communities to enhance both their capacity to protect themselves from animal intrusions and their understanding of the importance of sloth bears as seed dispersal, to the forest ecosystem could have significant benefits for both people and bear.

\section{Acknowledgements}

The Gujarat State forest department with the field survey assistants and the budget supported our work. We would like to say special thanks to Additional Principal Chief Conservator of Forest (Add. PCCF) wildlife and TRC (Training and Research Centre) of the State forest department of Gujarat. Thanks are also due to DFO, BAWLS, Palanpur and Forest staff of the forest divisions.

\section{Conflicts of interest}

The authors declare that there are no conflicts of interest related to this article.

\section{References}

Akhatar N, Bargali HS, Chauhan NPS (2004). Sloth bear habitat use in disturbed and unprotected areas of Madhya Pradesh, India. Ursus 15(2):203-211.

Champion HB, Seth SK (1968). A revised survey of the forest types of India. Government of India, Publication, New Delhi.

Chauhan NPS, Bargali HS, Akhtar N (1999). Human- sloth bear conflict in the state of Madhya Pradesh, India. Presented in the 12th international Conference on Bear Research and Management, Romania. UnpublishedMS.

Desai, AA, Baskaran N, VenkateshS (1997). Behavioural ecology of the sloth bear in Mudumalai Wildlife Sanctuary and National Park, Tamil Nadu. Report- A collaborative Project between Bombay Natural History Society and Tamil Nadu Forest Department.

Dharaiya N, Ratnayeke S (2009). Escalating human-sloth bear conflicts in North Gujarat: a tough time to encourage support for bear conservation. International Bear News 18(3):12-14.

Dharaiya N (2008). Study on the status, distribution and occurrence of certain rare and small mammals in North Gujarat region. Final Report Submitted to Gujarat Forest Research Institute pp 80.

Dharaiya N (2009). Evaluating habitat and human-bear conflicts in North Gujarat, India, to seek solution for human-bear coexistence. Final report submitted to The Ruffords Small Grants Foundation pp 44. (www.ruffordsmallgrants.org)
Garshelis DL, Joshi AR, Smith JLD (1999a). Estimating density and relative abundance of sloth bears. Ursus 11:87-98.

Garshelis DL, Joshi AR, Smith JLD, Rice CG (1999b). Sloth bear conservation action plan. In: Bear status survey and conservation action plan (eds. Servheen C, B Peython): IUCN / SSC bear and polar bear specialist groups. IUCN, Gland, Switzerland pp 309.

Gokula V (1991). Some aspects on the feeding habits of the sloth bear (Melursus ursinus) at Mundanthurai Wildlife Sanctuary, Tamil Nadu (South India). M.Sc. Thesis, A.V.C. College, Mannambandal, Tamil Nadu.

Gokula V, Sivaganesan N, Varadarajan M (1995). Food of the sloth bear (Melursus ursinus) in Mundanthurai Plateau, Tamil Nadu. Journal of Bombay Natural History Society 92(408):10.

Gopal R (1991). Ethological observations on the sloth bear (Melursus unsinus). Indian Forester 117(10):915-920.

Johnsingh AJT (1981). Ecology and behaviour of the dhole or Indian wild dog-Cuon alpinus. Pallas (1811):1-57.

Joshi AR, Garshelis DL, Smith JLD (1995). Home ranges of sloth bears in Nepal: implications for conservation. The Journal of Wildlife Management 59:204-214.

Joshi AR, Garshelis DL, Smith JLD (1997). Seasonal and habitat-related diets of sloth bears in Nepal. Journal of Mammalogy 78(2):584597.

Laurie A, Sedensticker J (1977). Behavioural ecology of the sloth Bears (Melursus ursinus). Journal ofZoology 182(2):187-204.

Litvaitis JA, Kane DM (1994). Relationship of hunting technique and hunter selectivity to composition of black bear harvest. Wildlife Society Bulletin 22(4):604-606.

Mewada T, Dharaiya N (2010). Seasonal dietary composition of sloth bear (Melursus unsinus) in the reserve forest of Vijaynagar, North Gujarat, India. Tiger Paper 37(2): 8-13.

Mewada TP (2015). Index of relative importance of the dietary proportions of sloth bear (Melursus ursinus) in semi-arid region. Notulae Scientia Biologicae 7(3):281-288.

Murthy RS, Sankar K (1995). Assessment of bear-man conflict in North Bilaspur Forest Division, Bilaspur, M. P. Wildlife Institute of India, Dehradun.

Pandey CN (2004). Gujarat's wild destinations. Gujarat Ecological Education and Research Foundation, Gandhinagar, Indiapp 52-56.

Ratnayeke S, van Manen FT, Padmalal UKGK (2007). Home ranges and habitat use of sloth bears Melursus ursinus inomatus in Wasgomuwa National Park,SriLanka. Wildlife Biology 13(3):272-284.

Rossell CR, Litvaitis JA (1991). A comparison of methods to estimate the distribution of low-density black bear populations. Transactions of the Northeast Section of the Wildlife Society 48:15-20.

Singh R, Chand K, Patel GA (2002). Management plan for Balaram Ambaji Wildlife Sanctuary. Research and Working circle, Ghandhinagar.

Yoganand K, Rice CG, Johnsingh AJT (2005). Evaluating Panna National Park with special reference to ecology of sloth bear (Melunsus ursinus). Final Project Report. Wildlife Institute of India, Dehradun, India. 